\title{
PENGARUH KOMPETENSI DAN PELAKSANAAN AUDIT INTERNAL DALAM MENUNJANG EFEKTIFITAS PENGENDALIAN INTERNAL PENJUALAN
}

\author{
Elisia $^{1}$; Stefanus Ariyanto ${ }^{2}$ \\ 1,2 PT Inti Dufree Promosindo, Menara Sudirman lantai 20, \\ Jln. Jend. Sudirman Kav. 60 Jakarta
}

\begin{abstract}
PT Inti Dufree Promosindo is a subsidiary of PT Sona Topas Tourism Industry, Tbk. The company is one of the biggest retail companies that sell local and imported products. This business is also called duty free shop. PT. Inti Dufree Promosindo have problems in evaluate the infuence of the effectiveness of its internal audit function towards sales internal control due to large number of sales transactions occurred. The research result shows that the auditor competence and audit process variable have low but significant influence to sales internal control effectiveness (Coefficient determination 22.7\%), and so that the audit process variable that have low but significant influence to sales internal control effectiveness (Coefficient determination 36.8\%). However, the combination of the two variables tested with linear regression shows that both variables simultaneously have strong influence to sales internal control effectiveness. Based on the result of multiple linier regression analysis the determination coefficient is $47,4 \%$. This shows that auditor competence and audit process simultaneously have a significant effect in supporting internal sales control effectiveness.
\end{abstract}

Keywords: audit, internal audit, internal control

\begin{abstract}
ABSTRAK
PT Inti Dufree Promosindo anak perusahaan dari PT Sona Topas Tourism Industry Tbk. Perusahaan ini merupakan perusahaan yang cukup besar, yang bergerak di bidang perdagangan eceran atau retail. Sedangkan kegiatan utama perusahaan adalah menjual produk-produk yang berasal dari dalam dan luar negeri. Perusahaan ini juga dikenal sebagai toko bebas bea atau duty free shop. Permasalahan yang sedang dihadapi perusahaan saat ini adalah menilai efektivitas internal audit ditinjau dari segi kompetensi dan pelaksanaan, terhadap pengendalian internal penjualan, karena volume penjualan yang sangat banyak. Oleh karena itu, penulis merasa perlu untuk melakukan analisis terhadap pengaruh variabel kompetensi auditor dan pelaksanaan audit terhadap efektifitas pengendalian internal. Hasil penelitian menunjukkan bahwa kompetensi auditor internal memiliki pengaruh yang rendah (koefisien determinasi 22.7\%) namun bersifat signifikan terhadap efektifitas pengendalian internal penjualan, sedangkan pelaksanaan audit internal memiliki pengaruh yang rendah (koefisien determinasi 36,8\%) terhadap efektifitas pengendalian internal penjualan. Sedangkan Berdasarkan hasil analisis regresi linier berganda, diketahui koefisien determinasi sebesar 0,474 atau 47,4\%, angka ini menunjukkan bahwa kompetensi dan pelaksanaan audit internal secara simultan berpengaruh cukup kuat dalam menunjang efektifitas pengendalian internal penjualan.
\end{abstract}

Kata kunci: audit, audit internal, pengendalian internal 


\section{PENDAHULUAN}

Dalam perkembangan dunia usaha yang semakin maju, serta situasi persaingan dan aktivitas bisnis semakin meningkat. Perusahaan dituntut untuk menjaga kestabilan usahanya, serta menjaga arah tujuan usaha awal perusahaan. Tujuan utama dari pembentukan perusahaan adalah untuk mencapai laba yang maksimal. Untuk mencapai tujuan tersebut perusahaan harus memanfaatkan dan mengelola bagian-bagian yang terdapat di dalam perusahaan secara efektif dan efisien. Namun dalam mencapai tujuan perusahaan tersebut, diperlukan suatu pengendalian internal terutama pada bagian penjualan. Karena bagian penjualan merupakan ujung tombak perusahaan dalam menghasilkan pendapatan, yang berguna untuk membiayai setiap keperluan operasional perusahaan, serta keperluan perusahaan lainnya.

PT Inti Dufree Promosindo (IDP) bergerak di bidang perdagangan retail dan lebih dikenal dengan sebutan toko bebas bea atau duty free shop dengan menawarkan produk barang impor dan produk lokal (dalam negeri) berkualitas tinggi kepada wisatawan domestik maupun wisatawan mancanegara. Perusahaan ini beroperasi dengan cara membuka gerai-gerai toko di bandara dan mengoperasikan sebuah pusat perbelanjaan yang diberi nama Bali Galleria, yang terletak di Denpasar, Bali. Saat ini perusahaan memiliki depertemen internal audit yang berada di bawah presiden direktur. Permasalahan yang ada dan belum terjawab dalam perusahaan ini dan ingin dijawab oleh penelitian ini adalah mengetahui pengaruh kompetensi audit internal terhadap efektifitas pengendalian internal atas penjualan di PT Inti Dufree Promosindo, pengaruh pelaksanaan audit internal terhadap efektifitas pengendalian internal atas penjualan di PT Inti Dufree Promosindo dan seberapa besar pengaruh kompetensi dan pelaksanaan audit internal secara simultan terhadap efektifitas pengendalian internal atas penjualan di PT Inti Dufree Promosindo.

Tujuan yang ingin dicapai dalam penelitian ini adalah untuk mengetahui (1) Pengaruh kompetensi audit internal dalam menunjang efektifitas pengendalian internal penjualan; (2) Pengaruh pelaksanaan audit internal yang dilakukan perusahaan dalam menunjang efektifitas pengendalian internal penjualan; (3) Mengetahui dan mengukur seberapa besar pengaruh kompetensi dan pelaksanaan audit internal dalam menunjang efektifitas pengendalian internal penjualan.

Manfaat yang diharapkan dari penelitian ini adalah sebagai berikut (1) Dapat memberikan bahan masukan atau rekomendasi yang penting dalam upaya peningkatan pengendalian internal penjualan, serta memberikan bahan pertimbangan untuk menentukan bagaimana menerapkan pelaksanaan audit internal yang layak, yang didukung oleh kompetensi audit internal yang memadai di dalam perusahaan; (2) Dapat memberikan wawasan, pengetahuan, dan pemahaman tentang perbandingan antara teori dengan praktek yang sebenarnya tentang kompetensi audit internal, pelaksanaan audit internal, dan efektifitas pengendalian internal penjualan; (3) dapat memberikan wawasan dan pengetahuan kepada pihak-pihak yang tertarik dengan penelitian ini, serta dapat memberikan informasi bagi mereka yang berminat menelaah lebih lanjut.

\section{METODE PENELITIAN}

Metode yang digunakan dalam penelitian adalah sebagai berikut (1) Jenis penelitian yang digunakan adalah penelitian pengujian hipotesis (kuantitatif); (2) Penelitian pengujian hipotesis yang digunakan adalah penelitian deskriptif; (3) Dimensi waktu penelitian adalah cross sectional; (4) Kedalaman penelitian yang dilakukan penulis mendalam tetapi melibatkan satu objek saja (studi kasus); (5) Metode pengumpulan data dilakukan dengan cara langsung dan tidak langsung yaitu secara langsung berupa wawancara, pembagian kuesioner, dan secara tidak langsung berupa data arsip; (6) Lingkungan penelitian yang dilakukan adalah lingkungan non-contrived setting atau lingkungan riil; 
(7) Unit analisisnya adalah individu, yaitu karyawan yang bekerja pada perusahaan tempat penulis melakukan studi kasus, yaitu pada PT Inti Dufree Promosindo anak perusahaan dari PT Sona Topas Tourism Industry Tbk., yang berkantor pusat di Jakarta; (8) Model Empiris berupa model regresi dengan variabel-variabel yang diteliti yaitu berupa dua variabel independen dan satu variabel dependen.

\section{HASIL DAN PEMBAHASAN}

PT Inti Dufree Promosindo merupakan anak perusahaan dari PT Sona Topas Tourism Industry Tbk., didirikan pada tahun 1990. PT Inti Dufee Promosindo (IDP) merupakan perusahaan retail yang mengoperasikan toko bebas bea atau duty free shop terbesar di Indonesia. PT Inti Dufee Promosindo (IDP) mendapat bantuan teknis dari Duty Free Shoppers (DFS) yang merupakan salah satu anak perusahaan penghasil barang-barang mewah yang bermutu tinggi yaitu Louis Vuitton Moet dan Hennessy (LVMH). DFS sendiri merupakan operator jaringan toko bebas bea terkemuka di dunia yang tersebar di 14 negara. Bentuk kerjasama atau afiliasi antara PT Inti Dufree Promosindo (IDP) dan anak perusahaan PT Arthamulia Indah (AMI) dengan DFS berupa pemberian jaminan purna jual atas barang-barang bebas bea yang dijual di seluruh toko bebas bea, yang berlogokan DFS dan jaminan tersebut berlaku di seluruh gerai DFS yang tersebar di seluruh dunia.

Saat ini PT Inti Dufee Promosindo (IDP) dan anak perusahaan dibawah pengelolaan dan pengawasan induk perusahaan, mengelola 11 toko bebas bea yang tersebar di Jakarta dan Bali dengan luas lantai lebih dari $10.007 \mathrm{~m}^{2}$. PT Inti Dufree Promosindo (IDP) merupakan perusahaan yang berada di bawah satu kesatuan manajemen dengan induk perusahaanya yaitu PT Sona Topas Tourism Industry Tbk., dan perusahaan ini tergabung dalam kelompok usaha (group) Mayapada. Jenis data yang digunakan oleh penulis dalam penelitian ini adalah jenis data primer yang diperoleh dengan cara membagikan kuesioner secara langsung kepada responden yang merupakan karyawan dari PT Inti Dufree Promosindo.

Sampel berasal dari jumlah karyawan (yang terkait dengan penelitian) yaitu sebanyak 42 orang, kemudian dihitung dengan menggunakan rumus perhitungan Taro Yamane yang dikutip dalam Sarwono (2006:h120) sehingga menghasilkan jumlah sampel yang diperlukan sebanyak 30 orang responden.

$$
n=\frac{N}{N\left(d^{2}\right)+1}=\frac{42}{42\left(0,1^{2}\right)+1}=29,577 \approx 30
$$

Keterangan:

$\mathrm{n}=$ sampel

$\mathrm{N}=$ populasi

$\mathrm{d}=$ presisi atau tingkat kesalahan $(0,1 ; 0,05 ; 0,01)$

Metode untuk pengumpulan sampel adalah metode desain probabilitas dengan teknik pengambilan sampel simple random sampling dan metode analisis data adalah metode analisis korelasi yaitu Pearson Product Moment dan dilanjutkan dengan regresi linier sederhana dan regresi linier berganda. Uji korelasi digunakan untuk mengetahui korelasi antar variabel dan tingkat signifikannya. Sedangkan uji regresi digunakan untuk mengetahui pengaruh antar variabel yang diteliti. Uji statistik dilakukan untuk menentukan apakah perbedaan atau hubungan yang terlihat pada sampel benar-benar ada atau hanya kebetulan, akibat pengambilan sampel. Pengujian hipotesis statistik merupakan prosedur yang memungkinkan pembuatan keputusan, yaitu keputusan untuk menolak atau menerima hipotesis yang sedang di uji. 
Berikut ini adalah variabel-variabel yang diuji:

$\mathrm{X}_{1}=$ Kompetensi audit Internal

$\mathrm{X}_{2}=$ Pelaksanaan audit Internal

$\mathrm{Y}=$ Efektifitas pengendalian internal penjualan

Terdapat tiga hipotesis yang diuji, adalah sebagai berikut :

Pengaruh kompetensi audit internal dalam menunjang efektifitas pengendalian internal penjualan.

Ho : Kompetensi audit internal $\left(\mathrm{X}_{1}\right)$ tidak memiliki pengaruh yang signifikan terhadap efektifitas pengendalian internal penjualan $(\mathrm{Y})$.

Ha: Kompetensi audit internal $\left(\mathrm{X}_{1}\right)$ memiliki pengaruh yang signifikan terhadap efektifitas pengendalian internal penjualan $(\mathrm{Y})$.

Pengaruh pelaksanaan audit internal dalam menunjang efektifitas pengendalian internal penjualan.

Ho : Pelaksanaan audit internal $\left(\mathrm{X}_{2}\right)$ tidak memiliki pengaruh yang signifikan terhadap efektifitas pengendalian internal penjualan $(\mathrm{Y})$.

Ha: Pelaksanaan audit internal $\left(\mathrm{X}_{2}\right)$ memiliki pengaruh yang signifikan terhadap efektifitas pengendalian internal penjualan $(\mathrm{Y})$.

Pengaruh kompetensi dan pelaksanaan audit internal dalam menunjang efektifitas pengendalian internal penjualan.

Ho : Kompetensi audit internal $\left(\mathrm{X}_{1}\right)$ dan pelaksanaan audit internal $\left(\mathrm{X}_{2}\right)$ tidak memiliki pengaruh yang signifikan terhadap efektifitas pengendalian internal penjualan $(\mathrm{Y})$.

$\mathrm{Ha}$ : $\quad$ Kompetensi audit internal $\left(\mathrm{X}_{1}\right)$ dan pelaksanaan audit internal $\left(\mathrm{X}_{2}\right)$ memiliki pengaruh yang signifikan terhadap efektifitas pengendalian internal penjualan $(\mathrm{Y})$.

Setelah analisis data dilakukan, selanjutnya dilakukan uji Koefisien Determinasi, uji Koefisien Regresi yang berupa Uji t dan Uji F.

Operasionalisasi variabel merupakan penjelasan dari bagian-bagian yang diteliti. Dan pada bagian operasionalisasi variabel dijelaskan mengenai variabel independen $(\mathrm{X})$ yang terdiri dari $\mathrm{X}_{1}$, dan $\mathrm{X}_{2}$, dan variabel dependen (Y). Selain itu dijelaskan sub variabel, indikator, skala, dan instrumen yang digunakan. Operasionalisasi variabel dalam penelitian ini dapat dijelaskan dalam tabel 1.

Tabel 1 Matriks Operasionalisasi Variabel

\begin{tabular}{|c|c|c|c|c|}
\hline Variabel & Sub variabel & Indikator & Skala & Instrumen \\
\hline \multicolumn{5}{|l|}{ Independen: } \\
\hline \multirow{4}{*}{$\begin{array}{l}\text { Kompetensi Audit } \\
\text { Internal }\left(\mathrm{X}_{1}\right)\end{array}$} & \multirow{4}{*}{$\begin{array}{l}\text { Kompetensi Audit Internal } \\
\text { berdasarkan Standar } \\
\text { Profesi Audit Internal }\end{array}$} & 1. Keahlian & \multirow{4}{*}{$\begin{array}{l}\text { Ordinal (Likert) yang } \\
\text { ditransformasi menjadi } \\
\text { interval }\end{array}$} & \multirow[t]{4}{*}{ Kuesioner } \\
\hline & & 2. Kecermatan Profesional & & \\
\hline & & 3. Pengembangan Profesional yang & & \\
\hline & & Berkelanjutan (PPL) & & \\
\hline \multirow{4}{*}{$\begin{array}{l}\text { Pelaksanaan Audit } \\
\text { Internal }\left(\mathrm{X}_{2}\right.\end{array}$} & \multirow[t]{4}{*}{ Kegiatan Audit Internal } & 1. Program audit internal & \multirow{4}{*}{$\begin{array}{l}\text { Ordinal (Likert) yang } \\
\text { ditransformasi menjadi } \\
\text { interval }\end{array}$} & \multirow[t]{4}{*}{ Kuesioner } \\
\hline & & 2. Pelaksanaan audit internal & & \\
\hline & & 3.Laporan hasil audit internal & & \\
\hline & & 4.Tindak lanjut audit internal & & \\
\hline \multirow{8}{*}{$\begin{array}{l}\text { Dependen: } \\
\text { Efektifitas } \\
\text { Pengendalian } \\
\text { Internal Penjualan } \\
\text { (Y) }\end{array}$} & \multirow{6}{*}{$\begin{array}{l}\text { Terpenuhinya unsur- unsur } \\
\text { pengendalian internal atas } \\
\text { penjualan }\end{array}$} & & \multirow{6}{*}{$\begin{array}{l}\text { Ordinal (Likert) yang } \\
\text { ditransformasi menjadi } \\
\text { interval }\end{array}$} & \multirow{5}{*}{ Kuesioner } \\
\hline & & 1. Lingkungan pengendalian & & \\
\hline & & 2. Penilaian resiko & & \\
\hline & & 3. Kegiatan pengendalian & & \\
\hline & & 4. Informasi dan komunikasi & & \\
\hline & & 5. Pemantauan & & \\
\hline & \multirow{2}{*}{$\begin{array}{l}\text { Pencapaian tujuan } \\
\text { pengendalian intern atas } \\
\text { penjualan }\end{array}$} & $\begin{array}{l}\text { 1. Efektifitas dan efisiensi operasional } \\
\text { 2. Keandalan laporan keuangan }\end{array}$ & \multirow{2}{*}{$\begin{array}{l}\text { Ordinal (Likert) yang } \\
\text { ditransformasi menjadi } \\
\text { interval }\end{array}$} & \multirow[t]{2}{*}{ Kuesioner } \\
\hline & & $\begin{array}{l}\text { 3. Kepatuhan terhadap hukum dan } \\
\text { peraturan yang berlaku }\end{array}$ & & \\
\hline
\end{tabular}


Untuk memperoleh data dalam pengujian ini, penulis membagikan kuesioner kepada 30 orang responden. Jumlah sampel kuesioner tersebut dihasilkan dari hasil rumusan perhitungan jumlah sampel. Kuesioner tersebut, dibagikan kepada responden yang berasal dari karyawan perusahaan, yaitu kepada setiap karyawan yang terlibat dalam proses penjualan, seperti bagian penjualan, bagian operasional, bagian pengendali persediaan, bagian akuntansi, bagian keuangan dan bagian audit internal. Pengelompokkan profil responden terlihat pada Tabel 2.

Tabel 2 Data Profil Responden

\begin{tabular}{lcc}
\hline Jenis Kelamin & Jumlah & Persentase \\
\hline Laki-laki & 19 & $63 \%$ \\
Perempuan & 11 & $37 \%$ \\
Total & 30 & $100 \%$ \\
\hline & & \\
\hline Usia & Jumlah & Persentase \\
\hline 25 tahun & 3 & $10 \%$ \\
36 - 45 tahun & 12 & $40 \%$ \\
$>45$ tahun & 10 & \\
Total & 5 & $17 \%$ \\
& 30 & $67 \%$ \\
\hline
\end{tabular}

\begin{tabular}{lcc}
\hline Bagian & Jumlah & Persentase \\
\hline Penjualan & 12 & $40 \%$ \\
Operasional & 4 & $13 \%$ \\
Pengendali & 2 & $7 \%$ \\
Persediaan & 3 & $10 \%$ \\
Akuntansi & 5 & $17 \%$ \\
Keuangan & 4 & $13 \%$ \\
Audit Internal & 30 & $100 \%$ \\
Total & & \\
\hline & Jumlah & Persentase \\
\hline Lama Bekerja & 6 & $20 \%$ \\
$<=1$ tahun & 20 & $67 \%$ \\
1 s/d 5 tahun & 4 & $13 \%$ \\
$>=5$ tahun & 30 & $100 \%$ \\
Total & & \\
\hline
\end{tabular}

Dari data pada tabel di atas, dapat diketahui bahwa jumlah responden laki-laki ialah sebesar $63 \%$ dan responden perempuan sebesar $37 \%$. Kelompok usia terbanyak adalah antara 25 sampai 35 tahun, dengan persentase sebesar $40 \%$. Mayoritas responden terbesar yaitu sebanyak 12 orang atau $40 \%$ dari total keseluruhan responden berasal dari karyawan di bagian penjualan perusahaan. Masa kerja mayoritas responden yang dijadikan sampel adalah 1 sampai dengan 5 tahun dengan persentase sebesar $67 \%$.

Penelitian ini, menggunakan instrumen pengumpulan data berupa kuesioner. Langkah awal pengujian data adalah dengan mentransformasi data ordinal menjadi data interval. untuk memenuhi persyaratan analisis parametrik. Selanjutnya setelah data ditransformasi maka pengujian validitas dan pengujian reliabilitas akan dilakukan terhadap instrumen data. Selanjutnya data akan diuji kembali dengan uji asumsi klasik untuk memenuhi asumsi regresi linier berganda. Dan tahap terakhir adalah tahapan pengujian statistik atau hipotesis dengan menggunakan analisis pengujian yang telah ditetapkan. Pengujian instrumen data dilakukan dengan dua tahapan pengujian yaitu pengujian validitas, kemudian dilanjutkan dengan pengujian reliabilitas.

\section{Uji Validitas}

Pengujian validitas dilakukan dengan menggunakan tingkat kepercayaan sebesar 95\%, taraf signifikasi atau $\alpha$ sebesar 0,05 dan degree of freedom $(\mathrm{df}=\mathrm{n}-2)$ dan nilai $\mathrm{n}$ sebanyak 30 (jumlah responden). Maka diperoleh nilai df sebesar $28(\mathrm{df}=30-2)$, dengan demikian berdasarkan hasil perhitungan, maka diperoleh nilai $t_{\text {tabel }}$ sebesar 1,70 , serta untuk mendapatkan nilai $r_{\text {tabel }}$ dihitung dengan rumus $t / S Q R T$ ( $d f+t^{* * 2}$ ), sehingga diperoleh hasil nilai $r_{\text {tabel }}$ sebesar 0,31. Dasar pengambilan keputusan pada validitas adalah bila $r_{\text {hitung }}>0,31$, maka butir pertanyaan dianggap valid dan bila $\mathrm{r}_{\text {hitung }}<0,31$, maka butir pertanyaan dianggap tidak valid. 
Pengujian validitas untuk variabel $X_{1}, X_{2}$ sebagai variabel independen, dan variabel $Y$ sebagai variabel dependen ditampilkan di Tabel 3, 4, dan 5.

Tabel 3. Uji Validitas Variabel $\mathrm{X}_{1}$

\begin{tabular}{cccc}
\hline Pertanyaan & $\begin{array}{c}\mathrm{r} \\
\text { hitung }\end{array}$ & $\begin{array}{c}\mathrm{r} \\
\text { tabel }\end{array}$ & Kesimpulan \\
\hline P1 & 0.429 & 0,31 & Valid \\
P2 & 0.398 & 0,31 & Valid \\
P3 & 0.364 & 0,31 & Valid \\
P4 & 0.341 & 0,31 & Valid \\
P5 & 0.362 & 0,31 & Valid \\
P6 & 0.325 & 0,31 & Valid \\
P7 & 0.521 & 0,31 & Valid \\
P8 & 0.553 & 0,31 & Valid \\
P9 & 0.434 & 0,31 & Valid \\
P10 & 0.661 & 0,31 & Valid \\
\hline \multicolumn{4}{c}{ Sumber: pengolahan data }
\end{tabular}

Maka dari pengujian valitidas di atas, diketahui bahwa seluruh butir pertanyaan pada variabel $\mathrm{X}_{1}$ dinyatakan valid karena memiliki nilai $\mathrm{r}_{\text {hitung }}>0,31$.

Tabel 4. Uji Validitas Variabel $\mathrm{X}_{2}$

\begin{tabular}{cccc}
\multicolumn{4}{c}{ Tahap Pertama } \\
\hline Pertanyaan & r hitung & r tabel & Kesimpulan \\
\hline P1 & 0.323 & 0,31 & Valid \\
P2 & 0.522 & 0,31 & Valid \\
P3 & 0.401 & 0,31 & Valid \\
P4 & 0.721 & 0,31 & Valid \\
P5 & 0.356 & 0,31 & Valid \\
P6 & 0.41 & 0,31 & Valid \\
P7 & 0.577 & 0,31 & Valid \\
P8 & 0.043 & 0,31 & Tidak Valid \\
P9 & 0.36 & 0,31 & Valid \\
P10 & 0.508 & 0,31 & Valid \\
P11 & 0.481 & 0,31 & Valid \\
P12 & 0.346 & 0,31 & Valid \\
P13 & 0.367 & 0,31 & Valid \\
P14 & 0.617 & 0,31 & Valid \\
P15 & 0.533 & 0,31 & Valid \\
P16 & 0.596 & 0,31 & Valid \\
P17 & 0.553 & 0,31 & Valid \\
P18 & 0.347 & 0,31 & Valid \\
\hline
\end{tabular}

\begin{tabular}{cccc}
\multicolumn{4}{c}{ Tahap Kedua } \\
\hline Pertanyaan & r hitung & r tabel & Kesimpulan \\
\hline P1 & 0.392 & 0,31 & Valid \\
P2 & 0.54 & 0,31 & Valid \\
P3 & 0.366 & 0,31 & Valid \\
P4 & 0.755 & 0,31 & Valid \\
P5 & 0.371 & 0,31 & Valid \\
P6 & 0.388 & 0,31 & Valid \\
P7 & 0.594 & 0,31 & Valid \\
P9 & 0.345 & 0,31 & Valid \\
P10 & 0.488 & 0,31 & Valid \\
P11 & 0.467 & 0,31 & Valid \\
P12 & 0.321 & 0,31 & Valid \\
P13 & 0.403 & 0,31 & Valid \\
P14 & 0.641 & 0,31 & Valid \\
P15 & 0.496 & 0,31 & Valid \\
P16 & 0.617 & 0,31 & Valid \\
P17 & 0.536 & 0,31 & Valid \\
P18 & 0.336 & 0,31 & Valid \\
\hline
\end{tabular}

Sumber: pengolahan data

Dari pengujian bahwa butir pertanyaan ke 8 bernilai kurang dari nilai $t_{\text {tabel. }}$. Maka item ke 8 tersebut tidak dapat diikutsertakan dalam pengujian selanjutnya.

Selanjutnya dilakukan pengujian validitas tahap kedua untuk memastikan tingkat validitas butir pertanyaan yang telah valid di pengujian tahap pertama. Dan hasil pengujian tahap kedua, diketahui bahwa seluruh butir pertanyaan pada variabel $\mathrm{X}_{2}$ dinyatakan valid karena memiliki nilai $\mathrm{r}>$ 0,31 . 
Tabel 5 Uji Validitas Variabel Y

Tahap Pertama

\begin{tabular}{lrcc}
\hline Pertanyaan & r hitung & r tabel & Kesimpulan \\
\hline P1 & 0.491 & 0,31 & Valid \\
P2 & 0.664 & 0,31 & Valid \\
P3 & 0.396 & 0,31 & Valid \\
P4 & 0.424 & 0,31 & Valid \\
P5 & 0.718 & 0,31 & Valid \\
P6 & 0.78 & 0,31 & Valid \\
P7 & 0.454 & 0,31 & Valid \\
P8 & 0.637 & 0,31 & Valid \\
P9 & 0.713 & 0,31 & Valid \\
P10 & 0.523 & 0,31 & Valid \\
P11 & 0.475 & 0,31 & Valid \\
P12 & 0.401 & 0,31 & Valid \\
P13 & 0.529 & 0,31 & Valid \\
P14 & 0.475 & 0,31 & Valid \\
P15 & 0.478 & 0,31 & Valid \\
P16 & 0.361 & 0,31 & Valid \\
P17 & 0.028 & 0,31 & Tidak Valid \\
P18 & 0.637 & 0,31 & Valid \\
P19 & 0.713 & 0,31 & Valid \\
P20 & 0.228 & 0,31 & Tidak Valid \\
P21 & 0.716 & 0,31 & Valid \\
P22 & 0.554 & 0,31 & Valid \\
P23 & 0.434 & 0,31 & Valid \\
P24 & 0.481 & 0,31 & Valid \\
P25 & 0.659 & 0,31 & Valid \\
P26 & 0.417 & 0,31 & Valid \\
\hline & & &
\end{tabular}

Tahap Kedua

\begin{tabular}{|c|c|c|c|}
\hline Pertanyaan & r hitung & $\mathrm{r}$ tabel & Kesimpulan \\
\hline P1 & 0.493 & 0,31 & Valid \\
\hline P2 & 0.674 & 0,31 & Valid \\
\hline P3 & 0.405 & 0,31 & Valid \\
\hline P4 & 0.423 & 0,31 & Valid \\
\hline P5 & 0.683 & 0,31 & Valid \\
\hline P6 & 0.784 & 0,31 & Valid \\
\hline P7 & 0.465 & 0,31 & Valid \\
\hline P8 & 0.65 & 0,31 & Valid \\
\hline P9 & 0.715 & 0,31 & Valid \\
\hline P10 & 0.526 & 0,31 & Valid \\
\hline P11 & 0.471 & 0,31 & Valid \\
\hline P12 & 0.409 & 0,31 & Valid \\
\hline P13 & 0.549 & 0,31 & Valid \\
\hline P14 & 0.452 & 0,31 & Valid \\
\hline P15 & 0.475 & 0,31 & Valid \\
\hline P16 & 0.381 & 0,31 & Valid \\
\hline P18 & 0.65 & 0,31 & Valid \\
\hline P19 & 0.715 & 0,31 & Valid \\
\hline P21 & 0.725 & 0,31 & Valid \\
\hline $\mathrm{P} 22$ & 0.554 & 0,31 & Valid \\
\hline $\mathrm{P} 23$ & 0.407 & 0,31 & Valid \\
\hline P24 & 0.478 & 0,31 & Valid \\
\hline P25 & 0.664 & 0,31 & Valid \\
\hline $\mathrm{P} 26$ & 0.431 & 0,31 & Valid \\
\hline
\end{tabular}

Sumber: pengolahan data

Dari pengujian bahwa butir pertanyaan ke 17 dan ke 20 bernilai kurang dari nilai $t_{\text {tabel. }}$ Maka kedua item tersebut tidak dapat diikutsertakan dalam pengujian selanjutnya. Hasil pengujian tahap kedua, disimpulkan bahwa seluruh butir pertanyaan variabel $Y$ pada pengujian validitas tahap kedua telah diyatakan valid.

Pengujian reliabilitas untuk variabel-variabel independen $\left(\mathrm{X}_{1}, \mathrm{X}_{2}\right)$, dan variabel dependen $(\mathrm{Y})$ adalah sebagai berikut:

Tabel 6 Uji Reliabilitas Variabel

\begin{tabular}{lcc}
\hline & Cronbach's Alpha & N of Items \\
\hline $\mathrm{X}_{1}$ & .764 & 10 \\
$\mathrm{X}_{2}$ & .855 & 17 \\
$\mathrm{Y}$ & .919 & 24 \\
\hline \multicolumn{3}{c}{ Sumber: pengolahan data }
\end{tabular}

Dari Tabel 6 di atas, dapat disimpulkan bahwa variabel $\mathrm{X}_{1}$ (Kompetensi Audit Internal) dinyatakan reliabel $\left(0,764>0,60\left(\mathrm{r}_{\text {tabel }}\right)\right)$, variabel $\mathrm{X}_{2}$ (Pelaksanaan Audit Internal) juga dinyatakan reliabel $\left(0,855>0,60\left(\mathrm{r}_{\text {tabel }}\right)\right)$, dan variabel Y (Efektifitas Pengendalian Internal Penjualan) dinyatakan reliabel $\left(0,919>0,60\left(\mathrm{r}_{\text {tabel }}\right)\right)$. 


\section{Pengujian Asumsi Klasik}

Pengujian asumsi klasik adalah pengujian yang dilakukan untuk memenuhi asumsi regresi linier berganda. Pengujian asumsi klasik diperlukan untuk memastikan hasil analisis regresi yang digunakan terbebas dari gejala multikolinearitas, gejala heterokedastisitas, dan memenuhi asumsi normalitas, dan linearitas. Sehingga model regresi yang digunakan dapat menghasilkan hasil analisis yang dapat dipertanggung jawabkan dan tidak bias.

\section{Uji Normalitas}

Pengujian normalitas dilakukan dengan menggunakan rumus uji normalitas Kolmogorov Smirnov. Dalam pengujian normalitas, selain menggunakan rumusan Kolmogorov Smirnov juga menggunakan plot kenormalan atau Q-Q Plot pada masing-masing variabel yang diteliti. Pengujian normalitas masing-masing variabel terdapat pada Tabel 7.

Tabel 7 Uji Normalitas

\begin{tabular}{lcccrrc}
\hline & \multicolumn{3}{c}{ Kolmogorov-Smirnov } & \multicolumn{3}{c}{ Shapiro-Wilk } \\
\hline & Statistic & Df & Sig. & Statistic & Df & Sig. \\
\hline Kompetensi Audit Internal $\left(\mathrm{X}_{1}\right)$ & .132 & 30 & .190 & .967 & 30 & .471 \\
Pelaksanaan Audit Internal & .141 & 30 & .131 & .947 & 30 & .143 \\
Efektifitas Pengendalian Internal & .099 & 30 & $.200^{*}$ & .969 & 30 & .513 \\
Penjualan (Y) & & & & & &
\end{tabular}

Berdasarkan Tabel 7 di atas bila dibandingkan antara nilai Sig yang diperoleh dengan kriteria pengujian yang telah ditetapkan, maka menghasilkan kesimpulan sebagai berikut: (1) Variabel independen $\left(\mathrm{X}_{1}\right)$ memiliki nilai Sig $=0,190>0,05$, selain itu berdasarkan Gambar 1 plot-plot yang dihasilkan menunjukkan rentangan yang berada kurang lebih dalam satu garis lurus. Dengan demikian, maka data variabel $\mathrm{X}_{1}$ dinyatakan berdistribusi normal, sehingga variabel tersebut dapat digunakan dalam analisis selanjutnya; (2) variabel independen $\left(\mathrm{X}_{2}\right)$ memiliki nilai $\mathrm{Sig}=0,131>0,05$, selain itu berdasarkan gambar, plot-plot yang dihasilkan menunjukkan rentangan yang berada kurang lebih dalam satu garis lurus. Dengan demikian, maka data variabel $\mathrm{X}_{2}$ dinyatakan berdistribusi normal, sehingga variabel tersebut dapat digunakan dalam analisis selanjutnya; dan (3) variabel dependen (Y) memiliki nilai Sig $=0,200>0,05$, selain itu berdasarkan gambar, plot-plot yang dihasilkan menunjukkan rentangan yang berada kurang lebih dalam satu garis lurus. Dengan demikian, maka data variabel Y dinyatakan berdistribusi normal, sehingga variabel tersebut dapat digunakan dalam analisis selanjutnya.
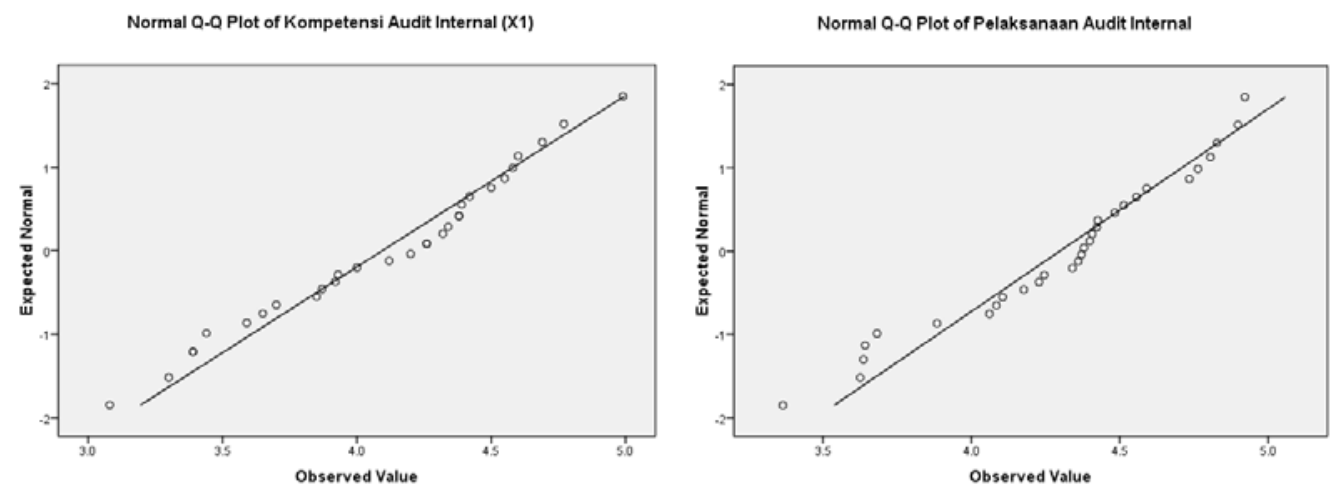


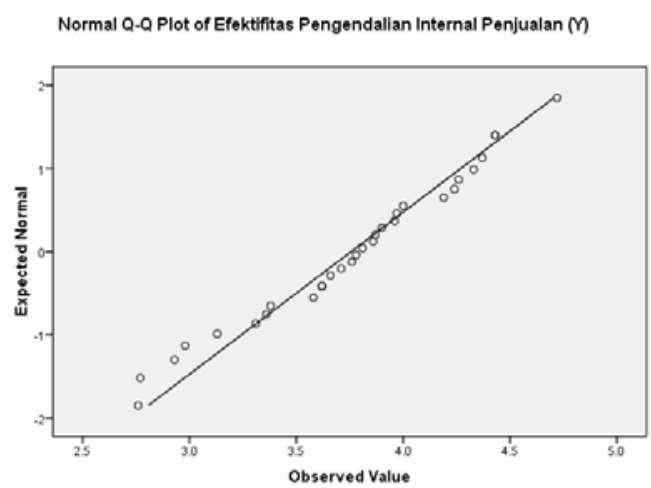

Gambar 1 Normal Q-Q Plot

\section{Pengujian Multikolinearitas}

Pengujian multikolinearitas dilakukan dengan menggunakan bantuan SPSS versi 16. Berikut ini adalah nilai Variance Inflation Factor (VIF) yang dihasilkan dari pengujian multikolinearitas dengan menggunakan bantuan SPSS versi 16:

Tabel 8 Uji Multikolinearitas ${ }^{\mathrm{a}}$

\begin{tabular}{cccc} 
& \multirow{2}{*}{ Model } & \multicolumn{2}{c}{ Collinearity Statistics } \\
\cline { 3 - 4 } & & Tolerance & VIF \\
\hline 1 & Kompetensi Audit Internal $\left(\mathrm{X}_{1}\right)$ & .903 & 1.108 \\
& Pelaksanaan Audit Internal $\left(\mathrm{X}_{2}\right)$ & .903 & 1.108 \\
\hline
\end{tabular}

Dependent Variable: Efektifitas Pengendalian Internal Penjualan (Y)

Berdasarkan Tabel 8, bila dibandingkan antara nilai VIF dan tolerance value yang diperoleh dengan kriteria pengujian yang telah ditetapkan, maka dapat disimpulkan bahwa nilai VIF yang dihasilkan untuk kedua variabel independen $\left(\mathrm{X}_{1}\right.$ dan $\left.\mathrm{X}_{2}\right)$ bernilai sekitar 1 , yaitu masing-masing sebesar 1,108 dan tolerance value juga mendekati 1 yaitu sebesar 0,903 untuk kedua variabel. Maka model regresi dinyatakan bebas dari gejala multikolinearitas.

Pengujian heterokedastisitas dilakukan dengan menggunakan rumusan uji Glejser. Hasil pengujian terdapat pada Tabel 9.

Tabel 9 Pengujian Heterokedastisitas Coefficientsa

\begin{tabular}{|c|c|c|c|c|c|c|}
\hline & \multirow[t]{2}{*}{ Model } & \multicolumn{2}{|c|}{ Unstandardized Coefficients } & \multirow{2}{*}{$\begin{array}{c}\begin{array}{c}\text { Standardized } \\
\text { Coefficients }\end{array} \\
\text { Beta }\end{array}$} & \multirow[t]{2}{*}{$\mathrm{t}$} & \multirow[t]{2}{*}{ SSig. } \\
\hline & & B & Std. Error & & & \\
\hline \multirow[t]{3}{*}{1} & (Constant) & 10.851 & 12.806 & & .847 & .404 \\
\hline & Kompetensi Audit Internal $\left(\mathrm{X}_{1}\right)$ & -.402 & .247 & -.314 & -1.632 & .114 \\
\hline & Pelaksanaan Audit Internal $\left(\mathrm{X}_{2}\right)$ & .160 & .162 & .191 & .992 & .330 \\
\hline
\end{tabular}

Dependent Variable: abresid 
Berdasarkan Tabel 9, bila dibandingkan antara nilai Sig $t_{\text {hitung }}$ yang diperoleh dengan kriteria pengujian yang telah ditetapkan maka dapat disimpulkan bahwa tidak terjadi hubungan antara nilai residu dengan variabel $\mathrm{X}_{1}$, karena nilai Sig $t_{\text {hitung }}$ untuk variabel $\mathrm{X}_{1}$ sebesar 0,114 $>0,05$ dan dapat disimpulkan pula tidak terjadi hubungan antara nilai residu dengan variabel $\mathrm{X}_{2}$ karena nilai Sig $\mathrm{t}_{\mathrm{hitung}}$ untuk variabel $\mathrm{X}_{2}$ sebesar 0,330 $>0,05$. Dengan demikian, disimpulkan bahwa tidak terjadi hubungan antara nilai residu dengan variabel independen secara keseluruhan, sehingga dapat dikatakan variabel dependen sepenuhnya dijelaskan oleh variabel independen. Hal ini mengindikasikan bahwa variabel independen terbebas dari gejala heterokedastisitas.

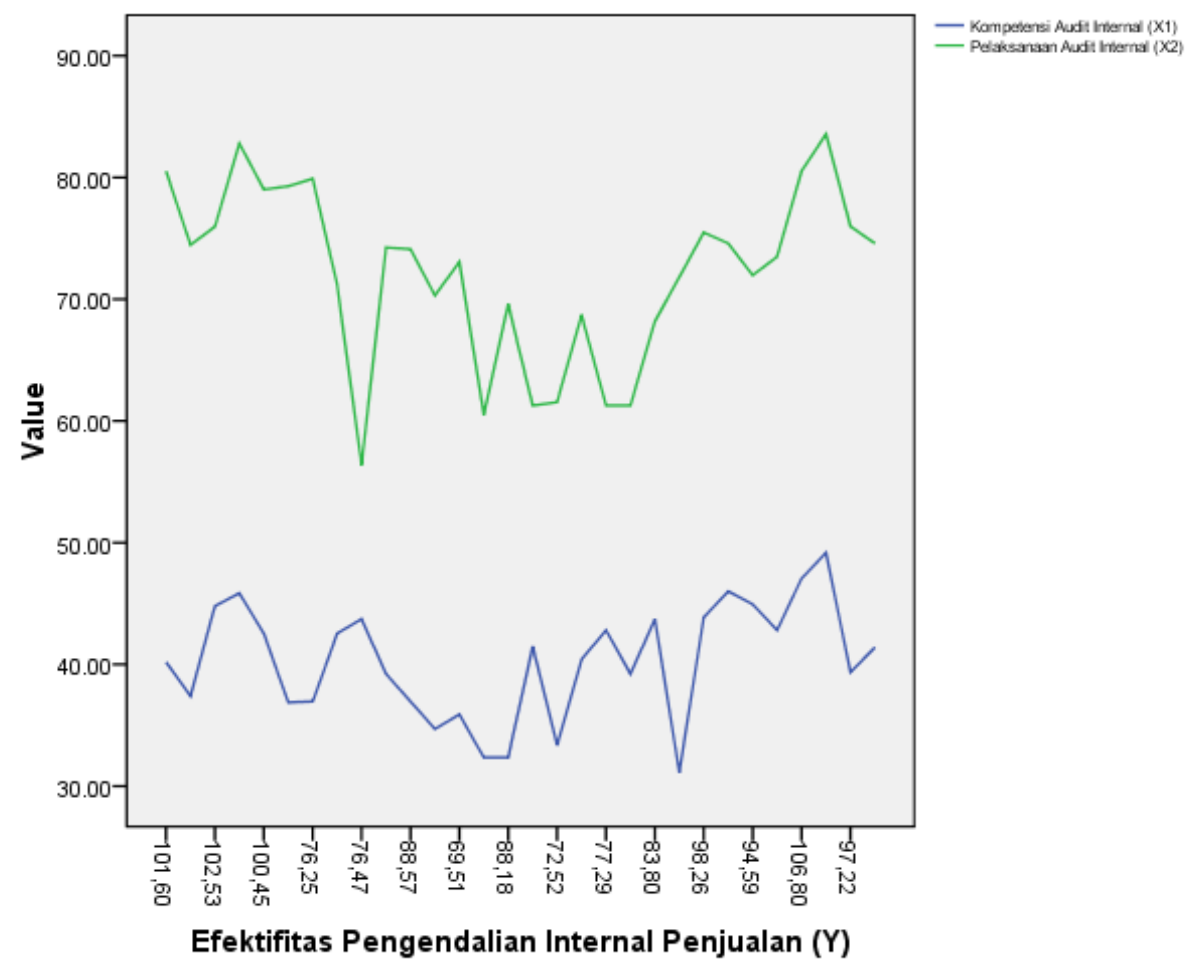

Gambar 2 Hasil Pengujian Linearitas

Dari gambar 2, dapat dilihat bahwa terjadi hubungan linearitas antara variabel independen $\left(\mathrm{X}_{1}\right.$ dan $\mathrm{X}_{2}$ ) terhadap variabel dependen $(\mathrm{Y})$. Hal ini disebabkan baik variabel $\mathrm{X}_{1}$ maupun variabel $\mathrm{sX}_{2}$ berfluktuasi seiring perubahan yang terjadi pada variabel dependen $(\mathrm{Y})$. Sehingga dapat disimpulkan bahwa analisis regresi dapat dilakukan dengan memasukkan kedua variabel independen $\left(\mathrm{X}_{1}\right.$ dan $\left.\mathrm{X}_{2}\right)$ tersebut dalam memprediksi variabel dependen $(\mathrm{Y})$.

\section{Regresi Linier Sederhana}

Analisis pengaruh secara parsial antara variabel independen (X1) terhadap variabel dependen (Y) menggunakan rumus uji regresi linier sederhana. Tabel 10 berisi hasil regresi linier sederhana yang digunakan untuk mengukur pengaruh kompetensi audit internal terhadap efektifitas pengendalian internal penjualan. 
Tabel 10 Korelasi

\begin{tabular}{|c|c|c|c|}
\hline & & $\begin{array}{l}\text { Efektifitas } \\
\text { Pengendalian } \\
\text { Internal Penjualan } \\
\text { (Y) }\end{array}$ & $\begin{array}{l}\text { Kompetensi } \\
\text { Audit Internal } \\
\left(\mathrm{X}_{1}\right)\end{array}$ \\
\hline \multirow[t]{2}{*}{ Pearson Correlation } & $\begin{array}{l}\text { Efektifitas Pengendalian } \\
\text { Internal Penjualan }(Y)\end{array}$ & 1.000 & .478 \\
\hline & Kompetensi Audit Internal $\left(\mathrm{X}_{1}\right)$ & .478 & 1.000 \\
\hline \multirow[t]{2}{*}{ Sig. (1-tailed) } & $\begin{array}{l}\text { Efektifitas Pengendalian } \\
\text { Internal Penjualan }(\mathrm{Y})\end{array}$ & . & .004 \\
\hline & Kompetensi Audit Internal $\left(\mathrm{X}_{1}\right)$ & .004 & . \\
\hline \multirow[t]{2}{*}{$\mathrm{N}$} & $\begin{array}{l}\text { Efektifitas Pengendalian } \\
\text { Internal Penjualan }(\mathrm{Y})\end{array}$ & 30 & 30 \\
\hline & Kompetensi Audit Internal $\left(\mathrm{X}_{1}\right)$ & 30 & 30 \\
\hline
\end{tabular}

Berdasarkan Tabel 10, diketahui bahwa korelasi atau hubungan antara variabel kompetensi audit internal $\left(\mathrm{X}_{1}\right)$ dan efektifitas pengendalian internal penjualan $(\mathrm{Y})$ sebesar 0,478 . Berdasarkan hasil korelasi tersebut maka dapat disimpulkan bahwa hubungan antara kompetensi audit internal $\left(\mathrm{X}_{1}\right)$ dan efektifitas pengendalian internal penjualan $(\mathrm{Y})$ memiliki hubungan yang cukup kuat dan searah (karena hasilnya bernilai positif).

Hipotesis:

Ho: Kompetensi audit internal $\left(\mathrm{X}_{1}\right)$ tidak memiliki korelasi yang signifikan dengan efektifitas pengendalian internal penjualan $(\mathrm{Y})$.

Ha : Kompetensi audit internal $\left(\mathrm{X}_{1}\right)$ memiliki korelasi yang signifikan dengan efektifitas pengendalian internal penjualan $(\mathrm{Y})$.

Dasar pengambilan keputusan:

- Jika nilai probabilitas $\mathrm{Sig} \geq 0,05$, maka Ho diterima, dan Ha ditolak.

- Jika nilai probabilitas Sig $\leq 0,05$, maka Ho ditolak, dan Ha diterima.

Keputusan :

Sig $=0,004$, yang artinya $0,004<0,05$. Maka Ho ditolak, dan Ha diterima. Sehingga dapat disimpulkan bahwa terdapat korelasi yang signifikan antara variabel $\mathrm{X}_{1}$ dengan variabel $\mathrm{Y}$.

Tabel 11 Koefisien $\mathrm{X}_{1}$ terhadap $\mathrm{Y}$

\begin{tabular}{|c|c|c|c|c|c|c|}
\hline & \multirow[t]{2}{*}{ Model } & \multicolumn{2}{|c|}{$\begin{array}{l}\text { Unstandardized } \\
\text { Coefficients }\end{array}$} & \multirow{2}{*}{$\begin{array}{c}\text { Standardized } \\
\text { Coefficients }\end{array}$} & \multirow[t]{2}{*}{$\mathrm{t}$} & \multirow[t]{2}{*}{ SSig. } \\
\hline & & $\mathrm{B}$ & Std. Error & & & \\
\hline \multirow[t]{2}{*}{1} & (Constant) & 40.326 & 17.194 & & 2.345 & .026 \\
\hline & Kompetensi Audit Internal $\left(\mathrm{X}_{1}\right)$ & 1.221 & .424 & .478 & 2.882 & .008 \\
\hline
\end{tabular}

a. Dependent Variable: Efektifitas Pengendalian Internal Penjualan (Y)

Tabel 11 menggambarkan persamaan regresi sederhana sebagai berikut :

$$
\begin{aligned}
& Y=a+b X_{1} \\
& Y=40,326+1,221 X_{1}
\end{aligned}
$$


Keterangan:

$\mathrm{X}_{1}=$ Kompetensi Audit Internal

$\mathrm{Y}=$ Efektifitas Pengendalian Internal Penjualan

Konstansta sebesar 40,326 menyatakan bahwa jika tidak ada kompetensi audit internal $\left(\mathrm{X}_{1}\right)$ maka efektifitas pengendalian internal penjualan (Y) adalah 40,326 sedangkan koefisien regresi sebesar 1,221 menyatakan bahwa setiap penambahan (karena tanda + ) satu skor, maka kompetensi audit internal $\left(\mathrm{X}_{1}\right)$ akan memberikan kenaikan skor sebesar 1,221.

Analisis pengaruh secara parsial antara variabel independen $\left(\mathrm{X}_{2}\right)$ terhadap variabel dependen (Y) menggunakan rumus uji regresi linier sederhana dengan dibantu oleh SPSS versi 16. Berikut ini adalah hasil tabel-tabel regresi linier sederhana yang digunakan untuk mengukur pengaruh pelaksanaan audit internal terhadap efektifitas pengendalian internal penjualan:

Tabel 12 Korelasi $\mathrm{X}_{2}$ terhadap $\mathrm{Y}$

\begin{tabular}{|c|c|c|c|}
\hline & & $\begin{array}{l}\text { Efektifitas } \\
\text { Pengendalian } \\
\text { Internal } \\
\text { Penjualan (Y) }\end{array}$ & $\begin{array}{l}\text { Pelaksanaan } \\
\text { Audit Internal } \\
\left(\mathrm{X}_{2}\right)\end{array}$ \\
\hline \multirow[t]{2}{*}{ Pearson Correlation } & $\begin{array}{l}\text { Efektifitas Pengendalian } \\
\text { Internal Penjualan }(\mathrm{Y})\end{array}$ & 1.000 & 619 \\
\hline & $\begin{array}{l}\text { Pelaksanaan Audit Internal } \\
\left(\mathrm{X}_{2}\right)\end{array}$ & .619 & 1.000 \\
\hline \multirow[t]{2}{*}{$\begin{array}{l}\text { Sig. } \\
\text { (1-tailed) }\end{array}$} & $\begin{array}{l}\text { Efektifitas Pengendalian } \\
\text { Internal Penjualan }(\mathrm{Y})\end{array}$ & . & .000 \\
\hline & $\begin{array}{l}\text { Pelaksanaan Audit Internal } \\
\left(\mathrm{X}_{2}\right)\end{array}$ & .000 & . \\
\hline \multirow[t]{2}{*}{$\mathrm{N}$} & $\begin{array}{l}\text { Efektifitas Pengendalian } \\
\text { Internal Penjualan }(\mathrm{Y})\end{array}$ & 30 & 30 \\
\hline & $\begin{array}{l}\text { Pelaksanaan Audit Internal } \\
\left(\mathrm{X}_{2}\right)\end{array}$ & 30 & 30 \\
\hline
\end{tabular}

Berdasarkan tabel 12, diketahui bahwa korelasi atau hubungan antara variabel pelaksanaan audit internal $\left(\mathrm{X}_{2}\right)$ dan efektifitas pengendalian internal penjualan $(\mathrm{Y})$ sebesar 0,619 . Berdasarkan hasil korelasi tersebut maka dapat disimpulkan bahwa hubungan antara pelaksanaan audit internal $\left(\mathrm{X}_{2}\right)$ dan efektifitas pengendalian internal penjualan (Y) memiliki hubungan yang kuat dan searah (karena hasilnya bernilai positif).

Hipotesis:

Ho : Pelaksanaan audit internal $\left(\mathrm{X}_{2}\right)$ tidak memiliki korelasi yang signifikan dengan efektifitas pengendalian internal penjualan $(\mathrm{Y})$.

Ha: Pelaksanaan audit internal $\left(\mathrm{X}_{2}\right)$ memiliki korelasi yang signifikan dengan efektifitas pengendalian internal penjualan $(\mathrm{Y})$.

Dasar pengambilan keputusan:

- Jika nilai probabilitas $\mathrm{Sig} \geq 0,05$, maka Ho diterima, dan Ha ditolak.

- Jika nilai probabilitas Sig $\leq 0,05$, maka Ho ditolak, dan Ha diterima.

Keputusan:

Sig $=0,000$, yang artinya $0,000<0,05$. Maka Ho ditolak, dan Ha diterima. Sehingga dapat disimpulkan bahwa terdapat korelasi yang signifikan antara variabel $\mathrm{X}_{2}$ dengan variabel $\mathrm{Y}$. 
Tabel 13 Koefisien $\mathrm{X}_{2}$ terhadap $\mathrm{Y}$

\begin{tabular}{|c|c|c|c|c|c|c|}
\hline & \multirow[t]{2}{*}{ Model } & \multicolumn{2}{|c|}{$\begin{array}{l}\text { Unstandardized } \\
\text { Coefficients }\end{array}$} & \multirow{2}{*}{$\begin{array}{c}\text { Standardized } \\
\text { Coefficients } \\
\text { Beta }\end{array}$} & \multirow[t]{2}{*}{$\mathrm{t}$} & \multirow[t]{2}{*}{ SSig. } \\
\hline & & $\mathrm{B}$ & Std. Error & & & \\
\hline \multirow[t]{2}{*}{1} & (Constant) & 14.630 & 18.036 & & .811 & .424 \\
\hline & Pelaksanaan Audit Internal $\left(\mathrm{X}_{2}\right)$ & 1.038 & .249 & .619 & 4.174 & .000 \\
\hline
\end{tabular}

a. Dependent Variable: Efektifitas Pengendalian Internal Penjualan (Y)

Tabel di atas, menggambarkan persamaan regresi linier sederhana sebagai berikut :

$$
\begin{aligned}
& Y=a+b_{2} X_{2} \\
& Y=14,630+1,038 X_{2}
\end{aligned}
$$

Keterangan :

$\mathrm{Y}=$ Efektifitas Pengendalian Internal Penjualan

$\mathrm{X}_{2}=$ Pelaksanaan Audit Internal

Konstansta sebesar 14,630 menyatakan bahwa jika tidak ada pelaksanaan audit internal $\left(\mathrm{X}_{2}\right)$ maka efektifitas pengendalian internal penjualan (Y) adalah 14,630 sedangkan koefisien regresi sebesar 1,038 menyatakan bahwa setiap penambahan (karena tanda + ) satu skor, maka pelaksanaan audit internal $\left(\mathrm{X}_{2}\right)$ akan memberikan kenaikan skor sebesar 1,038.

Tabel 14 adalah tabel regresi linier berganda yang digunakan untuk mengukur pengaruh secara simultan antara kompetensi dan pelaksanaan audit internal terhadap efektifitas pengendalian internal penjualan:

\begin{tabular}{|c|c|c|c|c|}
\hline & & $\begin{array}{l}\text { Efektifitas } \\
\text { Pengendalian Internal } \\
\text { Penjualan (Y) }\end{array}$ & $\begin{array}{l}\text { Kompetensi } \\
\text { Audit Internal } \\
\left(\mathrm{X}_{1}\right)\end{array}$ & $\begin{array}{l}\text { Pelaksanaan Audit } \\
\text { Internal }\left(\mathrm{X}_{2}\right)\end{array}$ \\
\hline \multirow[t]{3}{*}{$\begin{array}{l}\text { Pearson } \\
\text { Correla-tion }\end{array}$} & $\begin{array}{l}\text { Efektifitas Pengendalian Internal } \\
\text { Penjualan (Y) }\end{array}$ & 1.000 & .478 & .619 \\
\hline & Kompetensi Audit Internal $\left(\mathrm{X}_{1}\right)$ & .478 & 1.000 & .312 \\
\hline & Pelaksanaan Audit Internal $\left(\mathrm{X}_{2}\right)$ & .619 & .312 & 1.000 \\
\hline \multirow{3}{*}{$\begin{array}{l}\text { Sig. } \\
\text { tailed) }\end{array}$} & $\begin{array}{l}\text { Efektifitas Pengendalian Internal } \\
\text { Penjualan (Y) }\end{array}$ & . & .004 & .000 \\
\hline & Kompetensi Audit Internal $\left(\mathrm{X}_{1}\right)$ & .004 & . & .047 \\
\hline & Pelaksanaan Audit Internal $\left(\mathrm{X}_{2}\right)$ & .000 & .047 & . \\
\hline \multirow[t]{3}{*}{$\mathrm{N}$} & $\begin{array}{l}\text { Efektifitas Pengendalian Internal } \\
\text { Penjualan }(\mathrm{Y})\end{array}$ & 30 & 30 & 30 \\
\hline & Kompetensi Audit Internal $\left(\mathrm{X}_{1}\right)$ & 30 & 30 & 30 \\
\hline & Pelaksanaan Audit Internal $\left(\mathrm{X}_{2}\right)$ & 30 & 30 & 30 \\
\hline
\end{tabular}

Tabel 14 Korelasi $\mathrm{X}_{1}$, dan $\mathrm{X}_{2}$ dengan $\mathrm{Y}$

Berdasarkan Tabel 14, diketahui bahwa korelasi atau hubungan antara variabel kompetensi audit internal $\left(\mathrm{X}_{1}\right)$ dan pelaksanaan audit internal $\left(\mathrm{X}_{2}\right)$ dan efektifitas pengendalian internal penjualan (Y) sebesar 0,312. Berdasarkan hasil korelasi tersebut maka dapat disimpulkan bahwa hubungan antara kompetensi audit internal $\left(\mathrm{X}_{1}\right)$ dan pelaksanaan audit internal $\left(\mathrm{X}_{2}\right)$ dan efektifitas pengendalian internal penjualan (Y) memiliki hubungan yang cukup rendah dan searah (karena hasilnya bernilai positif). 
Hipotesis :

Ho : Kompetensi audit internal $\left(\mathrm{X}_{1}\right)$ dan pelaksanaan audit internal $\left(\mathrm{X}_{2}\right)$ tidak memiliki korelasi yang signifikan dengan efektifitas pengendalian internal penjualan $(\mathrm{Y})$.

Ha : Kompetensi audit internal $\left(\mathrm{X}_{1}\right)$ dan pelaksanaan audit internal $\left(\mathrm{X}_{2}\right)$ memiliki korelasi yang signifikan dengan efektifitas pengendalian internal penjualan $(\mathrm{Y})$.

Dasar pengambilan keputusan :

- Jika nilai probabilitas $\mathrm{Sig} \geq 0,05$, maka Ho diterima, dan Ha ditolak.

- Jika nilai probabilitas Sig $\leq 0,05$, maka Ho ditolak, dan Ha diterima.

Keputusan :

Sig $=0,047$, yang artinya $0,047<0,05$. Maka Ho ditolak, dan Ha diterima. Sehingga dapat disimpulkan bahwa terdapat korelasi yang signifikan antara variabel $\mathrm{X}_{1}$, dan $\mathrm{X}_{2}$ dengan variabel $\mathrm{Y}$.

Tabel 15 Coefficients $X_{1}$, dan $X_{2}$ terhadap $Y$

\begin{tabular}{|c|c|c|c|c|c|}
\hline \multirow[t]{2}{*}{ Model } & \multicolumn{2}{|c|}{$\begin{array}{l}\text { Unstandardized } \\
\text { Coefficients }\end{array}$} & \multirow{2}{*}{$\begin{array}{l}\text { Standardized } \\
\text { Coefficients } \\
\text { Beta }\end{array}$} & & \multirow[t]{2}{*}{ Sig. } \\
\hline & & Std. Error & & & \\
\hline (Constant) & -5.974 & 19.490 & & -.307 &. .762 \\
\hline Kompetensi Audit Internal $\left(\mathrm{X}_{1}\right)$ & .807 & .375 & .316 & 2.150 &. .041 \\
\hline Pelaksanaan Audit Internal $\left(\mathrm{X}_{2}\right)$ & .873 & .246 & .521 & 3.545 & .001 \\
\hline
\end{tabular}

a. Dependent Variable: Efektifitas Pengendalian Internal Penjualan (Y)

Tabel 15 menggambarkan persamaan regresi linier berganda sebagai berikut :

$$
\begin{aligned}
& Y=a+b X_{1}+b_{2} X_{2} \\
& Y=-5,974+0,807 X_{1}+0,873 X_{2}
\end{aligned}
$$

Keterangan :

$\mathrm{X}_{1}=$ Kompetensi Audit Internal

$\mathrm{X}_{2}=$ Pelaksanaan Audit Internal

$\mathrm{Y}=$ Efektifitas Pengendalian Internal Penjualan

Konstansta sebesar -5,974 menyatakan bahwa jika tidak ada kompetensi audit internal $\left(\mathrm{X}_{1}\right)$ dan pelaksanaan audit internal $\left(\mathrm{X}_{2}\right)$ maka nilai efektifitas pengendalian internal penjualan $(\mathrm{Y})$ adalah $-5,974$ lalu koefisien regresi $X_{1}$ sebesar 0,807 menyatakan bahwa setiap penambahan (karena tanda + ) satu skor, maka kompetensi audit internal $\left(\mathrm{X}_{1}\right)$ akan memberikan kenaikan skor sebesar 0,807 dan kemudian koefisien regresi $\mathrm{X}_{2}$ sebesar 0,873 menyatakan bahwa setiap penambahan (karena tanda + ) satu skor, maka pelaksanaan audit internal $\left(\mathrm{X}_{2}\right)$ akan memberikan kenaikan skor sebesar 0,873 .

\section{Uji Hipotesis}

Pengujian statistik merupakan suatu prosedur yang memungkinkan pembuatan keputusan, yaitu keputusan untuk menolak atau menerima hipotesis yang sedang di uji.

Hipotesis 1 :

Pengaruh kompetensi audit internal dalam menunjang efektifitas pengendalian internal penjualan.

Ho : Kompetensi audit internal $\left(\mathrm{X}_{1}\right)$ tidak memiliki pengaruh yang signifikan terhadap efektifitas pengendalian internal penjualan $(\mathrm{Y})$.

Ha : Kompetensi audit internal $\left(\mathrm{X}_{1}\right)$ memiliki pengaruh yang signifikan terhadap efektifitas pengendalian internal penjualan $(\mathrm{Y})$. 
Tabel 16 Hasil Perhitungan Regresi Linear Sederhana pada Tabel Coefficients

\begin{tabular}{ccc}
\hline \multicolumn{1}{c}{ Variabel } & $\mathbf{T}$ & Sig. \\
\hline Kompetensi Audit Internal $\left(\mathrm{X}_{1}\right)$ & 2.882 & .008 \\
Pelaksanaan Audit Internal $\left(\mathrm{X}_{2}\right)$ & 4.174 & .000 \\
\hline
\end{tabular}

Dari hasil perhitungan Regresi Linear Berganda pada Tabel 16 diperoleh nilai $t_{\text {hitung }}$ sebesar 2,882 dan nilai Sig sebesar 0,008 bila dibandingkan dengan nilai $t_{\text {tabel }}$ sebesar 2,052 dan nilai probabilitas 0,05 , maka $t_{\text {hitung }} 2,882>$ nilai $t_{\text {tabel }} 2,052$ dan Sig $0,008<0,05$. Sehingga dapat diputuskan bahwa Ho ditolak dan Ha diterima yang berarti kompetensi audit internal $\left(\mathrm{X}_{1}\right)$ memiliki pengaruh yang signifikan terhadap efektifitas pengendalian internal penjualan (Y).

Hipotesis 2 :

Pengaruh pelaksanaan audit internal dalam menunjang efektifitas pengendalian internal penjualan.

Ho : Pelaksanaan audit internal $\left(\mathrm{X}_{2}\right)$ tidak memiliki pengaruh yang signifikan terhadap efektifitas pengendalian internal penjualan $(\mathrm{Y})$.

Ha: Pelaksanaan audit internal $\left(\mathrm{X}_{2}\right)$ memiliki pengaruh yang signifikan terhadap efektifitas pengendalian internal penjualan $(\mathrm{Y})$.

Berdasarkan tabel Ringkasan Hasil Perhitungan Regresi Linear Berganda pada Tabel 16 diperoleh nilai $t_{\text {hitung }}$ sebesar 4,174 dan nilai Sig sebesar 0,000 bila dibandingkan dengan nilai $t_{\text {tabel }}$ sebesar 2,052 dan nilai probabilitas 0,05, maka $t_{\text {hitung }} 4,174>$ nilai $t_{\text {tabel }}$ 2,052 dan Sig 0,000<0,05 sehingga dapat diputuskan bahwa Ho ditolak dan Ha diterima yang berarti pelaksanaan audit internal $\left(\mathrm{X}_{2}\right)$ memiliki pengaruh yang signifikan terhadap efektifitas pengendalian internal penjualan $(\mathrm{Y})$.

Hipotesis 3 :

Pengaruh kompetensi dan pelaksanaan audit internal dalam menunjang efektifitas pengendalian internal penjualan.

Ho: Kompetensi audit internal $\left(\mathrm{X}_{1}\right)$ dan pelaksanaan audit internal $\left(\mathrm{X}_{2}\right)$ tidak memiliki pengaruh yang signifikan terhadap efektifitas pengendalian internal penjualan (Y).

Ha : Kompetensi audit internal $\left(\mathrm{X}_{1}\right)$ dan pelaksanaan audit internal $\left(\mathrm{X}_{2}\right)$ memiliki pengaruh yang signifikan terhadap efektifitas pengendalian internal penjualan $(\mathrm{Y})$.

Tabel 17 Hasil Perhitungan Regresi Linier Berganda

\begin{tabular}{rrr}
\hline Model & F & Sig \\
\hline Regression & 12.150 & $.000^{\mathrm{a}}$ \\
\hline
\end{tabular}

a. Predictors: (Constant), Pelaksanaan Audit Internal (X2), Kompetensi Audit Internal (X1)

b. Dependent Variable: Efektifitas Pengendalian Internal Penjualan (Y)

Dari hasil pengujian yang disajikan pada tabel 17 diperoleh nilai $F_{\text {hitung }}$ sebesar 12,150 dan nilai Sig sebesar 0,000 bila dibandingkan dengan nilai $F_{\text {tabel }}$ sebesar 12,150 dan nilai probabilitas 0,05 , maka $F_{\text {hitung }} 12,150>$ nilai $F_{\text {tabel }} 3,35$ dan Sig $0,000<0,05$. Sehingga dapat diputuskan bahwa Ho ditolak dan Ha diterima yang berarti kompetensi audit internal $\left(\mathrm{X}_{1}\right)$ dan pelaksanaan audit internal $\left(\mathrm{X}_{2}\right)$ memiliki pengaruh yang signifikan terhadap efektifitas pengendalian internal penjualan (Y). Dan koefisien korelasi ganda tersebut signifikan atau dapat diberlakukan pada pada populasi di mana sampel diambil. 


\section{SIMPULAN}

Berdasarkan pembahasan dan analisis pada bab sebelumnya mengenai pengaruh kompetensi dan pelaksanaan audit internal terhadap efektifitas pengendalian internal penjualan pada PT Inti Dufree Promosindo, maka diambil beberapa kesimpulan. Hasil analisis regresi linier sederhana dan regresi linier berganda, menunjukkan bahwa kompetensi audit internal yang tersusun dari beberapa indikator berupa keahlian, kecermatan profesional, dan Pengembangan Profesional yang Berkelanjutan (PPL) berdasarkan hasil analisis regresi linier sederhana, diketahui koefisien determinasi sebesar 0,229 atau 22,9\%, hal ini menunjukkan bahwa kompetensi audit internal tersebut memiliki pengaruh yang cukup rendah namun bersifat signifikan terhadap efektifitas pengendalian internal penjualan, sedangkan sisanya $77,1 \%$ dipengaruhi oleh faktor-faktor di luar penelitian ini. Dan berdasarkan hasil uji hipotesis, kompetensi audit internal memiliki pengaruh yang signifikan terhadap efektifitas pengendalian internal penjualan. Pelaksanaan audit internal sendiri, tersusun dari beberapa indikator berupa penyusunan program audit internal, pelaksanaan audit internal, pelaporan hasil audit internal, dan tindak lanjut audit internal. Koefisien determinasi sebesar 0,384 atau 38,4\% tersebut, menunjukkan bahwa pelaksanaan audit internal memiliki pengaruh yang lebih tinggi bila dibandingkan dengan kompetensi audit internal terhadap efektifitas pengendalian internal penjualan di dalam perusahaan, serta pengaruh tersebut bersifat signifikan. Sedangkan sisanya sebesar $61,6 \%$ dipengaruhi oleh faktor-faktor di luar penelitian ini. Dan berdasarkan hasil uji hipotesis, pelaksanaan audit internal memiliki pengaruh yang signifikan terhadap efektifitas pengendalian internal penjualan.

Hasil analisis regresi linier berganda, dengan koefisien determinasi sebesar 0,474 atau 47,4\%, menunjukkan bahwa kompetensi dan pelaksanaan audit internal secara simultan berpengaruh cukup kuat dalam menunjang efektifitas pengendalian internal penjualan. Sedangkan sisanya yaitu sebesar 0,526 atau 52,6\% dipengaruhi oleh faktor-faktor lain di luar penelitian ini. Dan berdasarkan hasil uji hipotesis, kompetensi dan pelaksanaan audit internal memiliki pengaruh secara simultan dan signifikan terhadap efektifitas pengendalian internal penjualan. Penelitian sebelumnya yang dilakukan oleh Dirmansyah (2005), dan Trudeau (2008) dengan jenis penelitian non parametrik, menggambarkan bahwa peranan audit internal memberi pengaruh kuat dan signifikan terhadap efektifitas pengendalian internal penjualan. Penelitian ini memiliki keunggulan dari penelitian sebelumnya, dalam segi penambahan jumlah variabel independen yang diteliti, pengembangan jenis penelitian yang digunakan yaitu berupa penelitian parametrik, selain itu jumlah sampel yang lebih besar yaitu sebanyak 30 orang responden, serta dalam penelitian ini juga dilakukan serangkaian pengujian data guna memenuhi asumsi penelitian parametrik dan asumsi regresi, yang tidak dilakukan sebelumnya. Hasil penelitian menunjukkan bahwa hasil analisis secara parsial atas kompetensi audit internal terhadap efektifitas pengendalian internal penjualan, maupun pelaksanaan audit internal terhadap efektifitas pengendalian internal penjualan memiliki pengaruh yang rendah namun signifikan. Sedangkan berdasarkan hasil analisis secara simultan menunjukkan bahwa kompetensi dan pelaksanaan audit internal mampu memberikan pengaruh yang cukup kuat dan signifikan terhadap efektifitas pengendalian internal penjualan.

\section{Saran}

Pengambilan keputusan manajemen dalam hal pencapaian laba yang maksimal dari kegiatan penjualan, dapat dicapai jika didasari oleh pengendalian internal yang efektif, perusahaan harus memperhatikan dua hal penting yaitu kompetensi dan pelaksanaan audit internal. Karena kedua hal tersebut mempengaruhi secara signifikan terhadap efektifitas pengendalian internal penjualan di dalam perusahaan. Kompetensi audit internal di dalam perusahaan harus lebih ditingkatkan kembali, khususnya pada peningkatan kemampuan berbasis teknologi informasi kepada para auditor internal perusahaan dengan memberikan fasilitas program pelatihan berbasis Information Technology (IT), sehingga auditor internal mampu mengidentifikasi setiap keganjilan ataupun kesalahan yang mungkin 
terjadi, dalam setiap kegiatan penjualan yang dilakukan dengan sistem komputerisasi. Dalam pelaksanaan audit, perusahaan harus lebih memperhatikan ketepatan waktu dalam perancangan program audit, yaitu dengan melakukan penjadwalan kembali atau rescheduling atas setiap pelaksanaan perancangan program audit, sehingga setiap prosedur pelaksanaan audit dapat berjalan dengan lebih efektif dan tepat waktu. Meningkatkan kesadaran karyawan di bagian penjualan atas pentingnya pengendalian internal dalam setiap kegiatan penjualan. Dengan mensosialisasikan secara intensif prosedur-prosedur pelaksanaan kegiatan penjualan yang sesuai dengan kebijakan dan peraturan perusahaan, serta memberikan sangsi yang tegas bagi setiap pelanggar kebijakan dan peraturan perusahaan, serta menciptakan program pengamanan secara terkomputerisasi baik dengan pengamanan sistem komputer, pengamanan dengan menggunakan teknologi CCTV atau kamera pengintai sebagai media untuk memantau kegiatan penjualan secara langsung, maupun dengan sistem pengamanan secara teknikal.

\section{DAFTAR PUSTAKA}

Dirmansyah. (2005). Peranan audit internal sebagai alat bantu manajemen dalam menunjang efektivitas pengendalian internal penjualan (studi kasus pada PT PINDAD (Persero) Bandung. Tesis S1 Tidak Dipublikasikan, Universitas Widyatama, Bandung.

Sarwono, J. (2006). Metode Penelitian Kuantitatif dan Kualitatif. Yogyakarta. Graha Ilmu.

Trudeau, U. (2008). Peranan audit internal dalam menunjang efektivitas pengendalian internal penjualan dan penagihan piutang (studi kasus pada PT. INTI Bandung). Tesis S1 Tidak Dipublikasikan, Universitas Widyatama, Bandung. 